\title{
Impact of Pharmaceutical Waste Generation and Handling on Environmental Health in Developing Countries: COVID - 19 Pandemic in Perspective!
}

\section{1,2* EJEROMEDOGHENE, O; ${ }^{3}$ NWOSISI, MC; ${ }^{4}$ TESI, GO; ${ }^{5}$ NORAGBON, EJ; ${ }^{* *}$ AKINYEYE, RO}

\author{
${ }^{* 1}$ Department of Chemistry, College of Physical Sciences, Federal University of Agriculture, PMB 2240 Abeokuta, Ogun State, Nigeria \\ ${ }^{2}$ School of Chemistry and Chemical Engineering, Southeast University, Jiangning District, Nanjing, Jiangsu Province, 211189, PR China \\ ${ }^{3}$ Department of Environmental Management and Toxicology, Federal University of Petroleum Resources, PMB 1221 Effurun, Delta State, \\ Nigeria \\ ${ }^{4}$ Department of Chemical Sciences University of Africa, Toru-Orua, Bayelsa State, Nigeria. \\ ${ }^{5}$ Department of Pediatrics, University College Hospital, PMB 5116, Ibadan, Nigeria \\ ${ }^{6}$ Department of Industrial Chemistry, Ekiti State University, P.M.B. 5363, Ado-Ekiti, Ekiti State, Nigeria \\ *Corresponding Author Email: oejeromedoghene@seu.edu.cn; Tel.: +86-18851663211; $2^{\text {nd }}$ Corresponding Author: \\ richard.akinyeye@eksu.edu.ng
}

\begin{abstract}
The World Health Organization (WHO) has declared the novel Covid-19 pandemic currently ravaging the world as a global mishap due to its wide-spreading across different nations. As the number of confirmed cases continues to increase daily, there will be a great need for the delivery of pharmaceutical palliatives to developing nations for them to manage the situation. Most pharmaceutical supplies used in many developing countries such as test kits and protective suits are a complex mixture of toxic and non-degradable compounds that are improperly disposed into open dump sites. The increase in Covid-19 cases and strategic attention to grapple will lead to multiple waste generation problems, thereby posing another health risk if not properly handled and disposed. In this review, we have highlighted the composition, categories, and hazards associated with pharmaceutical wastes and also appraised the current disposal practices and recommended some appropriate disposal methods of these associated wastes.
\end{abstract}

\section{DOI: https://dx.doi.org/10.4314/jasem.v25i3.12}

Copyright: Copyright $\left({ }_{0} 2021\right.$ Ejeromedoghene et al. This is an open access article distributed under the Creative Commons Attribution License (CCL), which permits unrestricted use, distribution, and reproduction in any medium, provided the original work is properly cited.

Dates: Received: 12 December 2020; Revised: 26 January 2021; Accepted: 12 February 2021

Keywords: Pharmaceutical wastes, Hazardous materials, Covid-19, Health risk, Waste handling

As the world continues to grapples with the "Novel Corona Virus" (Covid-19) pandemic, there will be an obvious need for large quantities of pharmaceuticals. Undoubtedly, these pharmaceuticals play a major role in reducing the mortalities and alleviating the distresses associated with the pandemic. Nevertheless, there would be major disposal problems of these pharmaceuticals in the offing in the future. Most notably, there will be a barrage of pharmaceuticals that may have expired or are almost expired upon receipt. The accumulation of pharmaceuticals that have almost passed its shelf life is largely not intentional, but the bureaucracies involved in taking delivery of some of these pharmaceutical supplies (especially in many developing countries) are largely to be blamed. Similarly, some of the pharmaceuticals that may have been labeled in unrecognizable languages; becomes unusable for particular needs, and may have been sent in unusually large amounts, would add up to the piles that end up as wastes. In addition, the lack of storage spaces, competent staff to operate equipment, abysmal management systems, and poor maintenance culture, will culminate in an increased number of accumulated pharmaceutical wastes to be disposed after some years (WHO 1999). The resultant pharmaceutical wastes over time are a great challenge in many countries in the world. It is an open secret that the disposal methods for these pharmaceuticals in developing countries are largely inappropriate and unsafe (Oladimeji-Salami et al 2017). The mainstream of the disposed pharmaceuticals in developing nations ends up in open dumps. Most of these pharmaceuticals are nonbiodegradable and there is the possibility of the immobilization of its chemical constituents unto another chemical substance and the transfer of such compounds into other environmental media (Babanyara et al 2013). The chemical compounds released in the open dumps could contaminate adjoining soils through lateral dispersion, leaching into the groundwater, and volatilization into the atmosphere (Agbozu and Nwosisi 2015). 
When pharmaceutical wastes are not properly disposed, the resulting human exposure via contact and ingestion could lead to a variety of ailments e.g. infections, skin irritations, cancers, infertility, genital deformities, respiratory and neurological disorders, etc. (NIOSH 2004). There is also the risk of contracting deadly diseases such as hepatitis, HIV, and other viral infections through sharp objects contaminated with infected blood. The transfers of chemicals from disposed pharmaceuticals thus pose a consequential high risk to human health. Based on the above, this review highlights the composition, categories, and hazards associated with pharmaceutical wastes and also appraised the current disposal practices as well as some appropriate disposal methods for these associated wastes.

Pharmaceutical Palliatives Used in Combating Covid-19: Many developing countries in the world, including some parts of Africa, are not well prepared and equipped to combat the emergency medical challenge occasioned by the Covid-19 pandemic. They, therefore, depend on assistance from developed nations for the supplies of medical needs in the form of palliatives to enable them to grabble with urgent incident cases in the short term. The major pharmaceuticals that are utilized in the fight against the Covid-19 pandemic (Plate 1) include but not limited to: test kits; surgical masks; gloves; scrubs; hospital gowns; headgears; thermometers; swab sticks; hand sanitizers and disinfectants; face shields; drugs; syringes; intravenous bags; protective suits; tubings and vials. A number of these pharmaceuticals can only be used once on a patient. This implies that they cannot also be reused and consequently have to be disposed off after its first use. According to the Centre for Disease Control and Prevention (CDC), over 23 million people have been tested with the aid of swab sticks for the novel virus in many parts of the world (CDC 2020). This paints a gloomy picture on the quantum of pharmaceuticals that would have been used and gets eventually disposed in the course of testing more citizens. This shows why it is pertinent for developing countries to be equipped with adequate technologies for appropriate disposal of their pharmaceutical wastes to prevent potential hazards that could be caused by them.

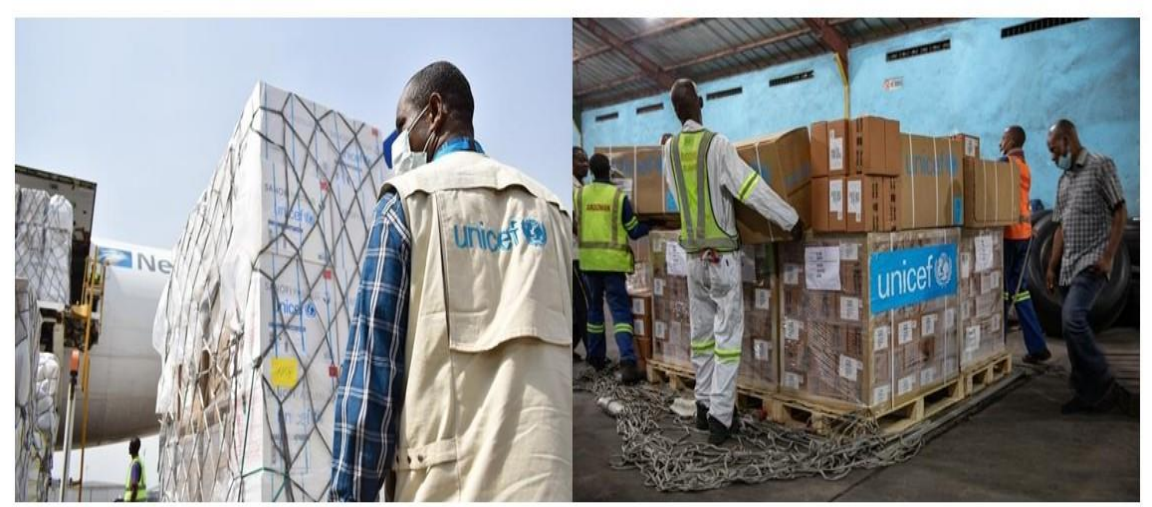

Plate 1: Medical worker receiving pharmaceutical deliveries for fighting the Covid-19 pandemic in Abuja, Nigeria. Source: (Joe and Drakopoulos 2020).

Classifications of Pharmaceutical Wastes: Pharmaceutical wastes are broadly categorized under hazardous and non-hazardous wastes. The pharmaceutical wastes that are dangerous and potentially harmful to human health or the environment are categorized as hazardous waste. Hazardous pharmaceutical wastes can be in the form of solids, liquids, enclosed gases, and sludges. As a result of their ability to cause severe harm even at their minute concentrations in the human environment, they are usually governed by strict sets of regulations. Only about $5-10 \%$ of pharmaceutical wastes turn out as hazardous. These hazardous pharmaceutical wastes can be further sub-divided into two categories: listed and characteristic wastes (USEPA 2017). Pharmaceutical wastes that are generated from discarded commercial chemical products are categorized as listed wastes. Characteristic wastes, on the other hand, exhibit hazardous properties such as ignitability, corrosivity, reactivity, and toxicity. Thus, this type of pharmaceutical wastes is highly regulated. Pharmaceutical wastes that are neither listed nor characteristic are considered solid wastes. Characteristic pharmaceutical wastes can be ignitable. They are potential fire hazards when they are stored, disposed, and transported. They are also capable of exacerbating a fire once it has started because they are highly flammable (Verma 2020). Similarly, characteristic pharmaceutical wastes can corrode materials and burn human skin. They are highly unstable and when heated, or compressed or mixed with water, can cause explosions and the release of 
toxic fumes, gases, and vapors. Using the USEPA definition for listed hazardous wastes, which are source linked, they are termed F-, K-, P-, and U-listed hazardous pharmaceutical wastes which are discussed briefly underneath.

F-listed: Although the sources of F-listed hazardous pharmaceutical wastes are non-specific (Hope and Rodewald 2017), however, these wastes originate from drug products generated during manufacturing and also through several other route like healthcare facilities e.g. methanol, methylene chloride, xylene, acetone, toluene, government, and school agencies. The F-listed wastes are of several sources, for example, F001 - F005 is from spent solvents, F006 F012, F019 are from metal finishing operations and electroplating activities, F020 - F023, F026, F028 are from dioxin burdened wastes, while wastes from chlorinated aliphatic hydrocarbons are tagged F024 F025. Others include the wood processing wastes (F032, F034, F035) while F039 is from multiple sources of leachates (U.S. Environmental Protection Agency, 2005).

K-listed: According to Heritage Environmental Services (HES) (HES 2013), K-listed wastes are source-specific, and also generated from manufacturing veterinary health facilities and solid wastes from certain industries with hazardous products. In this list, the wastes from wood processing are listed K001 like creosote and pentachlorophenol, inorganic pigment production (K002-K008), organic chemicals which are K- 001, -011, -030, -083, -095, $096,-103,-105,-107,-118,-136,-149,-151,-156$, $159,-161,-174,-175$, and $\mathrm{K}-181$, the inorganic chemical manufacturing companies that listed K-071, $-073,-106,-176$, and K-178 (Hope and Rodewald 2017); pesticide production waste included as K-031, $-043,-097,-099,-123,-126,-131$, and K-132; and the veterinary pharmaceuticals manufacturing company wastes included as K-084, -101 and K-102.

P-listed: In this group, when a lethal dose of $50 \mathrm{mg} / \mathrm{kg}$ of P-listed compounds is orally administered, the drug can be hazardous to environmental health. According to Hope and Rodewald, (Hope and Rodewald 2017) eight listed chemicals are Nitroglycerin (P-081), Nicotine (P-075) which include 1 -methyl-2-(3pyridyl)pyrrolidine and 3-(1 -methyl-2-pyrrolidyl) pyridine, Phentermine (P046), Epinephrine (P-042) sourced from emergency allergy kits, Warfarin $>0.3 \%$ (P-001), Physostigmine salicylate (P188), Physostigmine (P-204) and chemotherapy Arsenic trioxide (P-012). They originate from unused pesticides, pharmaceuticals, or chemicals. Other common ones in this class include acutely toxic metals and compounds like Arsenic (P-012), and cyanide salts. Manganese dimethyldithiocarbamate (P-126), Zinc phosphide (P-122), Phenylmercuryacetate (P092), chloropropionitrile (P-027) from pharmaceutical synthesis and Cyanide salts (P-030) from laboratories are also included in this list.

U-listed: These wastes are disposed in whole without been used for its original purpose. According to MPCA (MPCA 2011), the U-listed wastes includes discarded commercial chemicals products such as Uracil mustard (U237), Streptozotocin (U206), Melphalan (U150), Mitomycin (U010), Lindane (U129) from lice shampoo and spray, Mercury (U151), Hexachlorophene (U132), Selenium sulphide (U205) from shampoos and ointments, Resorcinol (U201), Accharin (U202), Reserpine (U200 and U201) which are from antihypertensive drugs, Dichlorodifluoromethane (U075), Chloral hydrates like Acetaldehyde, trichloro- (U034), Melphalan (U150), Phenol (U188), Diethylstilbestrol (U089), Trichloromonofluoromethane (U121), Paraldehyde (U182), and Chlorambucil (U035), Azaserine, Acetyl chloride, Hydrofluoric acid (U134), m-Cresol (U052), and Cumene (U055). Others include A2213 (U394), Acetic acid, (2,4-dichlorophenoxy)-, salts and esters (U240), Bendiocarbs (U278, U364) Acetic acid, Thallium (1+) salt (U-214), and 2Acetylaminofluorene (U005), Carbamic acids and its derivatives (U-372, -271, -280, -178, -373, - 409), and Carbofuran phenol (U-367). A comprehensive list is obtainable at MPCA (MPCA 2011). Dichlorobenzene (U071) from moth repellent and deodorizer blocks, the chemotherapy drugs like Duanomycin (U059), Cyclophosphamide and/or Cytoxan-Neosar, Cytoxan lyophilized/VHA Plus (U058).

Non-hazardous pharmaceutical wastes have no significant hazardous properties, but the hazardous components present in non-hazardous pharmaceutical wastes are however below the threshold for causing harm to human health. Therefore, the non-hazardous pharmaceutical wastes which initially have no significant hazardous properties can easily change to a hazardous waste with addition or removal of specific items from the waste stream.

Composition and Hazards Associated With Pharmaceutical Wastes: Pharmaceutical wastes are diverse and encompass all forms of wastes generated from over-the-counter medications, nutritional supplements, sunscreen products, personal (cosmetic) skincare products (Shannon and Woolridge 2011), fragrances, veterinary drugs, unused or expired drugs (Vallini and Townend 2010), remains of diagnostics tools, vials, syringes, fertilizers, pesticides, paraphernalia (gloves, masks, bottles) (Jaseem et al 2018) and intravenous therapy waste (Voudrias et al 
2012). They are excreted or introduced into the environment by pharmaceutical companies, from domestic sewage, through agricultural activities, leaching, and metabolized oral pharmaceuticals excreted through urine or excreta. Common examples include pharmaceutical products such as drugs, antibiotics, hormones, vaccines, steroids, and oncogenic (chemotherapy) substances. According to the Resource Conservation Recovery Act (RCRA) of the Environmental Protection Agency (EPA), certain drugs are tagged hazardous when introduced into the environment and must be disposed in a careful and recommended manner. This is because they are harmful to humans, animals, and the environment (lithospheric and hydrospheric flora and microbes). Additionally, they can be infectious, toxic, or radioactive in nature.

Composition of Pharmaceutical Wastes: Pharmaceutical wastes could be classified into nonhazardous and hazardous. Hazardous wastes constitute about $15 \%$ of the total pharmaceutical wastes. The World Health Organization opined that hospitals alone generate a daily amount of about $0.5 \mathrm{~kg}$ and $0.2 \mathrm{~kg}$ of hazardous waste in high- and low-income countries respectively (WHO 2018). However, their composition is described by their characteristics as listed wastes. The harmful or hazardous pharmaceutical wastes are not only limited to the expired medications that are discarded but also the containers that are used to store pharmaceutical contents like vials, which have trace quantity of the toxic and non-biodegradable constituents. When released into the environment, they are cytotoxic, genotoxic, carcinogenic, and mutagenic in some cases. Also, personal protective gear spilled pills and liquid medications are also classified as pharmaceutical wastes mostly generated in almost all health care facilities and pharmacies including cosmetic preparation discharges (Zafar 2019). Certain peculiar characteristics are attributed to these categories of waste which delimits them from non-hazardous wastes, for example, they are either corrosive, irritates, reactive, ignitable, or toxic. About 5\%-10\% of the components used in pharmaceutical products are harmful (Pines and Smith 2008).

Hazard elements in Pharmaceutical Wastes: The indiscriminate disposal of pharmaceutical wastes especially from expired and unused drugs can pose serious environmental hazards for humans, animals, plants, soil, and water bodies (Ali et al 2019; Hester and Harrison 2016). Over time, they become harmful to natural fauna and flora as they contaminate lakes, rivers, and streams (Kar et al 2020; Patel et al 2019). These wastes are a threat to biological entities and may cause several toxic effects ranging from genotoxicity, mutagenesis, anatomical aberrations, and physiological imbalances amongst others (Gotz et al 2019). These wastes have been detected in varying quantities in the soil, water bodies, aquatic sediments, and sludge; and under the nutrient cycle, they can concatenate in food webs, with an extended effect on humans (Roig and D'Acco 2016). Thus, these exposures would have negative effects on humans who eventually consume food from the terrestrial and aquatic environments (Ali et al 2019). Furthermore, the P- and K-listed hazardous wastes are the most essential pharmaceuticals that are more toxic. Therefore, the hazards associated with the use and indiscriminate disposal of these pharmaceutical wastes are consequent of the hazardous chemicals contained in it. Some of these chemical constituents are Polymer compounds, Arsenic trioxide (Trisenox), Dioxins, Chlorambucil (Leukeran), Uracil mustard, Diethystilbestrol (DES), Stilphostrol, Melphalan (Alkeran/L-PAM), Mitomycin-C, Mutamycin, Streptozotocin, Nitroglycerin, Epinephrine, Warfarin, Nicotine and Cyclophosphamide (Cytoxan-Neosar). The health implications associated with each are discussed underneath.

(a) Polymer compounds are the chief constituents of Covid-19 palliatives such as nose masks, surgical gloves, test kits, swabs, tubing, and vials, etc. These materials are made from non-biodegradable polymers such as polypropylene, polypropylene, polyesters, etc. which are the main source of phthalates in the environment. These compounds can stay in the environment for several years, thereby wreaking mild to severe havoc in different aspects of the ecosystem where they are deposited (Henneberry 2020; Kilinc 2015; Piotrowska et al 2020). As such, they can result in microplastic pollution, which is currently a growing concern in Africa. The inappropriate handling and disposal of these non-reusable items can lead to severe environmental and marine pollution with serious health implications if not properly managed.

(b) Arsenic trioxide is the major active formulation for the treatment of promyelocytic leukaemia but has been reported to cause cardiotoxic reactions during treatment (Haybar et al 2019). It is a medication given by injection into the vein, stored in a bottle, and produced under the trade name Arsenox or Trisenox. It can be injected into the small intestine from inhalation and skin contact. It causes cellular enzyme inactivation, impairs DNA repair and synthesis, causes vomiting, diarrhoea, abdominal pain, and nausea. It has been reported that it causes encephalopathy, peripheral neuropathy, and carcinogenic (Ratnaike 2003). Jahangirnejad et al. (Jahangirnejad et al 2020) reported that arsenic from cosmetic and agricultural 
productions contaminates drinking water and it is a carcinogenic metalloid that can cause mitochondrial and lysosomal damage and apoptosis in liver cells in rats. It is also found to be clastogenic and genotoxic in Dawley rats as investigated by Patlolla and Tchounwou (2005). The discarded bottles of Arsenox as hospital wastes eventually contaminate drinking water via leaching into aquatic systems.

(c) Dioxins also are known as dirty dozen with name 2,3,7,8-tetrachlorodibenzo-para-dioxin (TCDD) are persistent environmental pollutants found to accumulate in the food chain, in fatty tissues of animals, and humans through food. They are released into the environment from uncontrolled incineration activities from hospital, fertilizer, or pesticide usage (de Titto and Savino 2019). It damages the immune systems, and causes reproductive problems including developmental disorders; it impairs hormonal functions and is a precursor for cancer. In humans, it causes skin lesions (dark patches and chloracne) and alters liver functions (WHO 2016).

(d) Mitomycin $C$ also under the brand names Ametycine, MitoExtra or Mitoplus (6-amino-8[[(aminocarbonyl)oxy]methyl]-1,1aS, $2,8 \mathrm{~S}, 8 \mathrm{aR}, 8 \mathrm{bS}$ -

hexahydro-8a-methoxy-5-methyl-

azirino[2',3':3,4]pyrrolo[1,2-a]indole-4,7-dione)

exhibits acute toxicity, suspected to cause cancer. The compound can be inhaled or absorbed subcutaneously. It causes irritation of the skin; eye or respiratory tract as mostly experimented in mouse (Company et al. 2015). It has been detected in green algae in surface waters (Gouveia et al 2019) and thus poses a serious risk for humans as a predisposing factor for cancer (OECD 2019).

(e) Diethylstilbestrol synonymous with 4,4'[(1E)-1,2diethyl-1,2-ethenediyl]bis-phenol is classified as a carcinogenic substance that causes skin, respiratory tract, and eye corrosion and irritation. It is highly toxic to aquatic life forms as it has been reported to be carcinogenic, and damages fertility in animals (Company et al 2015).

(f) Nicotine is released into the environment by Tobacco producing companies or as cigarette waste (Qamar et al 2020), and it has a great hazardous impact on the climate, soil, and humans (Hendlin and Bialous 2020). Although nicotine is been sourced from plants, it can be absorbed subcutaneously during harvest in the rain. It is also responsible for the Green Tobacco Sickness (GTS), a function of wet nicotine poisoning (Achalli et al 2012; Park et al 2018). Nicotine from cigarette smoke reacts with indoor air pollutants to form toxic compounds e.g., nicotine and nitrous acid can create a carcinogenic compound called nitroamine ketone (4-(methylnitrosamino)-1-(3-pyridyl)-1butanone). It reacts with the ozone to form an ultrafine particle-sized secondary organic aerosol and also creates an unpleasant odor in residential areas (Matt et al 2017). Infants' exposure to this third-hand smoke embedded with nicotine may be vulnerable to it as it impairs organ development (McKnight and Spiller 2005). Nicotine entering landfills leachates, wastewater, and groundwater and may be a threat to human lives (WHO 2017).

(g) Cyclophosphamide is an oxazaphosphorine compound used in the production of chemotherapeutic drugs with cytostatic character and also used for the treatment of autoimmune diseases. Burge et al. (Buerge et al 2006) reported the presence of cyclophosphamide in wastewater and surface waters in Switzerland. The Organization for Economic Cooperation and Development (OECD) (OECD 2019) submitted it has carcinogenic, mutagenic, teratogenic, cardiogenic, and embryotoxic effects. These effects affect the reproductive biology and immunology. Taina (Tainá 2018) reported that the compound causes oxidative and DNA damages and alteration in burrowing behavior in Nereis diversicolor. The compound has been identified to inhibit reproduction in aquatic organisms and fishes as examined in rotifers (Russo et al 2018). Gouveia et al (2019) detected cyclophosphamide along with other cytostatic (antineoplastic) drug residues as one of the top five in different aquatic systems. These compounds are difficult to degrade in treatments plants and have been detected in hospital effluents (Hamon et al 2018), wastewater treatment plants influents and effluents (Isidori et al 2016), workspace isolators in Oncology Centers (Soteriades et al 2020) and surface waters (Usawanuwat et al 2014).

(h) Chlorambucil is one of the 14 frequently found antineoplastics in surface waters and effluents from hospitals that is carcinogenic to humans (Gouveia et al 2019). Gupta and Salvatore reported that the alkylating agent used to treat a broad spectrum of tumors is insoluble in water, and can be very detrimental when exposed to humans through inhalation, dermal contact or accidental ingestion (Gupta and Salvatore 2014). It interferes with RNA transcription and DNA replication. It causes seizures, abnormal vision, has psychiatric effects, myelosuppression, leukopenia, and pulmonary fibrosis and also toxic to the kidney and liver.

(i) Nitroglycerin is a nitrocellulose compound used in the production of resins, varnishes, adhesives, skin protectants in cosmetics, nail polishes, and inks (Mattos Simoes Mendonca et al 2015). It is insoluble in water and easily found in sediments. Oral or skin exposure in humans can disrupt women's menstrual cycle, allergic dermatitis affecting the victim's face and neck (Moreira et al 2017). It causes intravascular haemolysis and neuropathy. In the environment, it has been found in fish tissues in streams, it influences the 
chemical and physical properties of the aquatic habitat. It was found to be toxic to algal species in freshwater ecosystems (Kim 2014). Quinn (Quinn 2015) reported that in mammals it causes decreased weight gain, gross necropsy, and intestinal impaction in mice.

(j) Epinephrine (4-[(1R)-1-hydroxy-2(methylamino)ethyl]-1,2-benzenediol) is toxic when exposed to humans through skin contact. When inhaled, the potential hazards of the chemical compound could be irritation of the mucous membranes, upper respiratory tract, skin, and eyes (CCC 2019). Similar reactions and hazards are associated with Streptozotocin.

(k) Melphalan is a phenylalanine derivative of nitrogen mustard (cytotoxic organic compounds with the chloroethylamine functional group) which exhibits antineoplastic activities. It is known to be teratogenic, suspected to be reproductive toxicity (damaging fertility), causes skin irritation, and germ cell mutagenicity (NCBI 2020).

Current Disposal Practices of Pharmaceutical Wastes: Disposal practices of pharmaceutical wastes in many developing countries often fall below the requisite specifications. An effective waste management system dictates that wastes should be sorted, segregated, stored, collected, and then transported to final disposal (Emmanuel et al 2001). However, this is not the case with most healthcare establishments that generate pharmaceutical wastes in many African nations. There is no formal waste segregation being carried out in a number of their establishments, as most of the pharmaceutical waste generated are muddled together (Awodele et al 2016). There is hardly any distinction in the collection and storage of hazardous and non-hazardous pharmaceutical wastes. This is more worrisome because it has been established that non-hazardous wastes can easily become hazardous when mixed (Patil and Pokhrel 2005). Waste storage before collection is another upsetting episode in most healthcare institutions in many countries (Plate 2). There is usually a designated place where all the wastes are dumped within the premises of the healthcare establishment. In most instances, the wastes are not sorted, bagged, and are placed carelessly in large waste bins. The poor waste storage system makes the collection point to be a haven for scavengers, stray domestic animals, and a breeding ground for all kinds of disease vectors. Since most of these collection points are not covered, rainfall and other natural actions of meteorology worsen the situation. These wastes are usually washed into drains, watercourses, and eventually into the rivers thus endangering human and aquatic lives. Liquid pharmaceutical waste from diagnostic laboratories also finds its way into watercourses via open and shallow drainage systems in some healthcare establishments.
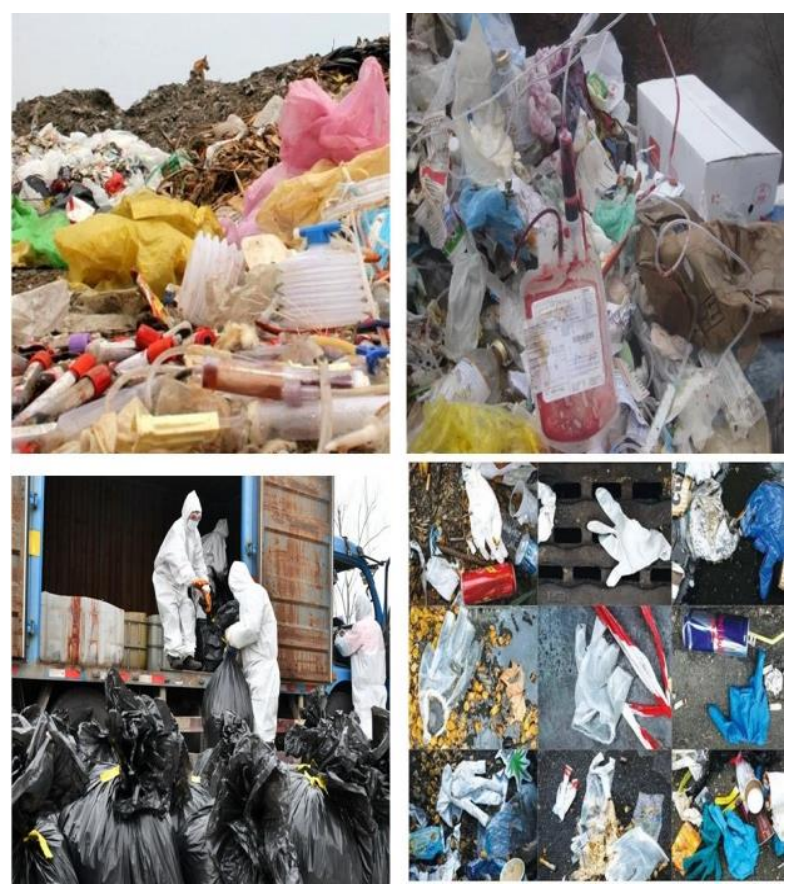

Plate 2: Pharmaceutical wastes generated due to Covid-19. Source: (Al Nasseri 2020; Bahagijo 2020).

These rivers and streams contaminated with pharmaceutical wastes are subsequently used to source water for irrigation and other farming purposes. The open burning of pharmaceutical wastes is widely practiced in some healthcare establishments. This is particularly dangerous because these wastes are not segregated, implying that both hazardous and nonhazardous materials are mixed and burnt together (Ngwuluka et al 2009). There will be a release of hyper doses of toxic compounds (as listed above) into the atmosphere as a result of combustion since some of the pharmaceutical wastes are cytotoxic, carcinogenic, and mutagenic to the human system (Gholap et al 2018).

In some cases, the pharmaceutical wastes are transported with open trucks to the final open dump. At these open dumps which are always mistaken for landfills, the wastes are buried by covering with a layer of earth. Periodically, they are burnt to reduce their quantity and make space available for another set of wastes. These landfills are non-engineered and are largely inappropriate for the disposal of pharmaceutical wastes. Due to its poor or unavailable structural design, the risk of water pollution is high. Materials leached from the pharmaceutical waste can permeate into the aquifer or flow into watercourses, 
thereby polluting drinking water (Agbozu and Nwosisi 2015). Likewise, scavengers can go into these sites, pick pharmaceutical wastes such as syringes, wash and reuse or reintroduce into the environment. Such practices would be deleterious to human health. Proper disposal of pharmaceutical wastes is based on policies and procedures of state and federal regulations environmental laws. The first port of call for the disposal of pharmaceutical waste is to return such wastes to the manufacturers or the donor agencies.

This is specifically apt for expired drugs and other pharmaceuticals that may have passed their shelf life. If this is practicable, it would solve the dilemma of improper disposal. Manufacturers are fully aware of the constituents of their products and the best way to safely dispose of such products. Pharmaceutical wastes containing antineoplastic have proven to be difficult in disposing and would, therefore, require expert attention for its safe disposal. Returning such kinds of waste to the manufacturers for disposal is highly recommended for developing countries. It shifts the burden of disposal and removes the likely human health impact that would have resulted from improper disposal.

However, care should be taken during the return of certain hazardous pharmaceutical wastes to prevent the boomerang effect. The returning agency should carefully consider the provisions of the regulation in the Basel Convention on the Trans-boundary Shipment of Hazardous Wastes (WHO 1999). The disposal of pharmaceutical wastes into landfills is another option that should be considered. Landfilling means placing wastes directly on land earmarked for a disposal site without prior treatment or preparation (Agbozu et al 2015).

The non-engineered landfill which is the most widely used in developing countries is inappropriate for the disposal of pharmaceutical wastes. An engineered sanitary landfill is therefore highly recommended for the disposal of pharmaceutical waste. Engineered sanitary landfills are properly designed and constructed with preference to the protection of the aquifer.

Developing nations are enjoined to upgrade their open dump waste disposal sites to the engineered sanitary landfills (Ferronato and Torretta 2019). Waste encapsulation is another highly effective method for the disposal of pharmaceutical waste. This involves immobilizing the pharmaceutical waste in containers made of impervious and non-reactive metals. These containers are then sealed with concrete, plastic, or steel and are either buried or transported to an engineered sanitary landfill for final disposal. Some pharmaceutical waste such as syrups and intravenous fluids can be diluted with a proportionate amount of water and flushed into sewers. However, it is advised that they should be flushed in smaller quantities over a longer period. High-temperature incineration is adequately suited for the disposal of pharmaceutical waste containing halogenated compounds. Cement kilns that operate at temperatures above $850^{\circ} \mathrm{C}$ are apt for the incineration of such pharmaceutical wastes. Since cement raw materials and combustion gases burn at temperatures of about $1450{ }^{\circ} \mathrm{C}$ and $2000{ }^{\circ} \mathrm{C}$ respectively, and the gas residence time at a severely high temperature is few seconds, organic compounds in the pharmaceutical wastes would be effectively disintegrated (WHO 2014).

Nigeria as well as other developing countries that have cement factories could benefit from this method of disposal of pharmaceutical wastes. If appropriate incinerators are unavailable, chemical decomposition of the pharmaceutical wastes in line with the recommendations of the manufacturer, and subsequent disposal in an engineered sanitary landfill, is recommended. A summary of the disposal methods recommended by the WHO for different categories of pharmaceutical wastes is presented in Table 1 .

Following the assertions of Fawzy et al (2018) and Mahadik (2016), it is obvious that harmful pharmaceutical wastes can be detrimental to terrestrial life, thus building an intentional strategy for its safe disposal is most pertinent. This will curtail poor waste disposal practices in pharmaceutical and health facilities across the globe. Some of the very effective ways being recommended are as follows:

a. Using environmentally friendly, safe, and favorable methods of treatment of hazardous should be imbibed. These treatment patterns include autoclaving, integrated steam treatment, and microwaving.

b. Gradual improvement of a comprehensive system to handle irresponsible handling and disposal of wastes should be pursued at different levels of government.

c. Promotion of policies and practices through different communication medium that encourage the process of reducing waste generation and differential sorting before disposal and

d. Institutionalizing awareness campaign and advocacy programs purposively for raising the knowledge and literacy of health workers on the risks involved in the illegal disposal of harmful wastes. 
Table 1: Pharmaceutical waste categories and appropriate disposal methods (Adapted from (WHO 1999))

\begin{tabular}{|c|c|c|}
\hline Category & Disposal methods & Comments \\
\hline Solids & Landfill & $\begin{array}{l}\text { No more than } 1 \% \text { of the daily municipal } \\
\text { waste should be disposed of daily in an } \\
\text { untreated form (non-immobilized) to a } \\
\text { landfill. }\end{array}$ \\
\hline Semi-solids & Waste encapsulation & \\
\hline \multirow[t]{2}{*}{ Powders } & Waste inertization & \\
\hline & 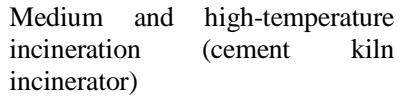 & \\
\hline Liquids & $\begin{array}{l}\text { Sewer } \\
\text { High-temperature incineration } \\
\text { (cement kiln incinerator) }\end{array}$ & Antineoplastics not to the sewer. \\
\hline Ampoules & $\begin{array}{l}\text { Crush ampoules and flush diluted } \\
\text { fluid to Sewer }\end{array}$ & Antineoplastics not to the sewer. \\
\hline \multirow[t]{3}{*}{$\begin{array}{l}\text { Anti-infective } \\
\text { drugs }\end{array}$} & Waste encapsulation & $\begin{array}{l}\text { Liquid antibiotics may be diluted with } \\
\text { water, left to stand for several weeks, and } \\
\text { discharged to a sewer. }\end{array}$ \\
\hline & Waste inertization & \\
\hline & 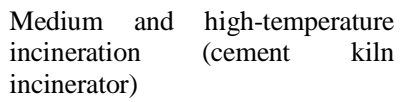 & \\
\hline \multirow[t]{4}{*}{ Antineoplastics } & Return to donor or manufacturer & Not to landfill unless encapsulated. \\
\hline & Waste encapsulation & Not to the sewer. \\
\hline & Waste inertization & No medium temperature incineration. \\
\hline & $\begin{array}{l}\text { Medium and high-temperature } \\
\text { incineration (cement kiln } \\
\text { incinerator) } \\
\text { (chemical decomposition) }\end{array}$ & \\
\hline \multirow{3}{*}{$\begin{array}{l}\text { Controlled } \\
\text { drugs }\end{array}$} & Waste encapsulation & Not to landfill unless encapsulated. \\
\hline & Waste inertization & \\
\hline & $\begin{array}{l}\text { Medium and high-temperature } \\
\text { incineration (cement kiln } \\
\text { incinerator) }\end{array}$ & \\
\hline $\begin{array}{l}\text { Aerosol } \\
\text { canisters }\end{array}$ & Landfill Waste encapsulation & Not to be burnt: may explode. \\
\hline \multirow[t]{2}{*}{ Disinfectants } & $\begin{array}{l}\text { To sewer or fast-flowing } \\
\text { watercourse: small quantities of } \\
\text { diluted disinfectants (max. } 50\end{array}$ & $\begin{array}{l}\text { No undiluted disinfectants to sewers or } \\
\text { watercourses. }\end{array}$ \\
\hline & liters per day under supervision) & $\begin{array}{l}\text { Maximum } 50 \text { liters per day diluted to } \\
\text { sewer or fast-flowing watercourse. } \\
\text { No disinfectants at all to slow-moving or } \\
\text { stagnant watercourses. }\end{array}$ \\
\hline $\begin{array}{l}\text { PVC plastic, } \\
\text { glass }\end{array}$ & Landfill & Not for burning in open containers. \\
\hline $\begin{array}{l}\text { Paper, } \\
\text { cardboard }\end{array}$ & Recycle, burn, landfill & \\
\hline
\end{tabular}

Conclusion: The handling of pharmaceutical wastes is a serious environmental concern that require strict and urgent attention. Therefore, managers of health facilities are encouraged to ensure that the appropriate disposal methods are adhered to succinctly by all health workers involved in the use, handling, and disposal of chemicals/wastes generated in the hospitals. Also, government environmental agencies at local, state, national, and international levels are hereby further reminded to ensure proper monitoring of the handling and disposal of pharmaceutical wastes in the various health facilities available in their jurisdiction such that all the WHO guidelines are properly enforced.
Acknowledgments: The authors wish to acknowledge scholarship council of Southeast University, Nanjing, China for supporting this work.

\section{REFERENCES}

Achalli, S; Shetty, SR; Babu, SG (2012). The Green

Hazards: A Meta-Analysis of Green Tobacco Sickness. Inter. J. Occup. Safety and Health, 2(1): 11-14

Agbozu, IE; Nwosisi, M (2015). Journal of Chemical , Biological and Physical Sciences Determination of Pollution Index between Active and Closed Dumpsites in Port Harcourt Metropolis. J. Chem., Biol. and Phy. Sci. 5(2): 2051-2061. 
Impact of Pharmaceutical Waste Generation and Handling.....

Agbozu, I; Nwosisi, M (2015). Leachate characterization of active and closed dump sites in Port Harcourt metropolis, Nigeria. Inter. J. Biol. and Chem. Sci. 9(2): 1107.

Agbozu, I; Oghama, O; Odhikori, J (2015). PhysicoChemical Characterization and Pollution Index Determination of Leachates from Warri Waste Dumpsite, Southern Nigeria. J. Appl. Sci. and Environ. Manage. 19(3): 361.

Al Nasseri, Z (2020). How Covid-19 medical waste processed in the Sultanate? Oman Daily Observer. https://www.omanobserver.om/howcovid-19-medical-waste-processed-in-thesultanate/. Accessed 16 July 2020

Ali, H; Khan, E; Ilahi, I (2019). Environmental chemistry and ecotoxicology of hazardous heavy metals: Environmental persistence, toxicity, and bioaccumulation. J. Chem. 2019(Cd). https://doi.org/10.1155/2019/6730305

Awodele, O; Adewoye, AA; Oparah, AC (2016). Assessment of medical waste management in seven hospitals in Lagos, Nigeria. BMC Pub. Health, 16(1): 1-11.

Babanyara, YY; Ibrahim, DB; Garba, T; Bogoro, AG; Abubakar, MY (2013). Poor Medical Waste Management ( MWM ) Practices and Its Risks to Human Health and the Environment: A Literature Review. Inter. J. Environ. Ecol. Geo. and Mining Eng. 7(11): 757-764.

Bahagijo, M (2020). Understanding Medical Waste Management to Curb the Transmission of COVID-19. Waste 4 Change. https://waste4change.com/understandingmedical-waste-management-to-curb-thetransmission-of-covid-19/. Accessed 12 June 2020

Buerge, IJ; Buser, HR; Poiger, T; Müller, MD (2006). Occurrence and fate of the cytostatic drugs cyclophosphamide and ifosfamide in wastewater and surface waters. Environ. Sci. and Technol. 40(23): 7242-7250.

CCC. (2019). Epinephrine. In M. Ann Arbor (Ed.), Cayman Chemical Company Safety Data Sheet (pp. 1-6). Cayman Chemical Company Inc.

CDC. (2020). Corona Virus Disease 2019 (COVID19): Cases, data and surveillance. Centre for
Disease Control and Prevention. https://www.cdc.gov/coronavirus/2019ncov/cases-updates/testing-in-us.html. Accessed 17 May 2020

Company, CC; Arbor, A; Company, CC (2015). Baicalein Section 1 . Identification of the Substance / Mixture and of the Company / Undertaking Section 2 . Hazards Identification Baicalein Section 4 . First Aid Measures Section 5. Fire Fighting Measures, (1907): 1-6.

de Titto, E; Savino, A (2019). Environmental and health risks related to waste incineration. Waste Manage. and Res. 37(10): 976-986.

Emmanuel, J; Pieper, U; Rushbrook, P; Stringer, R; Townend, W; Wilburn, S; Zghondi, R (2001). Safe management of wastes from health care activities. Bulletin of the World Health Organization, 79(2): 171.

Fawzy, ME; Abdelfattah, I; Abuarab, ME; Mostafa, E; Aboelghait, KM; El-Awady, MH (2018). Sustainable approach for pharmaceutical wastewater treatment and reuse: Case study. $J$. Environ. Sci. and Technol. 11(4): 209-219. https://doi.org/10.3923/jest.2018.209.219

Ferronato, N; Torretta, V (2019). Waste mismanagement in developing countries: A review of global issues. Inter. J. Environ. Res. and Pub. Health. 16(6).

Gholap, D; Chaturvedi P; Dikshit, R (2018). Ecological Analysis to Study Association between Prevalence of Smokeless Tobacco Type and Head-and-Neck Cancer. Indian J. Med. and Paediatric Oncology, 16-20.

Gotz, K; Courtier, A; Stein, M; Strelau, L; Sunderer, G; Vidaurre, R et al. (2019). Management of emerging public health issues and risks: multidisciplinary approaches to the changing environment. (B. Roig, K. Weiss, \& V. Thireau, Eds.). The Netherland: Academic Press, Amsterdam.

Gouveia, TIA; Alves, A; Santos, MSF (2019). New insights on cytostatic drug risk assessment in aquatic environments based on measured concentrations in surface waters. Environ. Inter. 133 (10): 105236.

Gupta, N; Salvatore, JR (2014). Chlorambucil. In P. Wexler (Ed.), Encyclopaedia of Toxicology (3rd 
ed., pp. 835-836). Amsterdam, the Netherland: Academic Press.

Hamon, P; Moulin, P; Ercolei, L; Marrot, B (2018). Oncological ward wastewater treatment by membrane bioreactor: Acclimation feasibility and pharmaceuticals removal performances. J. Water Pro. Eng. 21 (11), 9-26.

Haybar, H; Shahrabi, S; Rezaeeyan, H; Jodat, H; Saki, N (2019). Strategies to inhibit arsenic trioxideinduced cardiotoxicity in acute promyelocytic leukemia. J. Cell. Physiol. 234(9): 14500-14506. https://doi.org/10.1002/jcp.28292

Hendlin, YH; Bialous, SA (2020). The environmental externalities of tobacco manufacturing: A review of tobacco industry reporting. Ambio. 49(1): 1734

Henneberry, B (2020). How Surgical Masks are Made. Thomas Industry Update. https://www.thomasnet.com/articles/other/howsurgical-masks-are-made/\#: :text=Surgical face masks are made,meter ( $\mathrm{gsm})$ in density. Accessed 15 July 2020

HES (2013). What are K listed wastes? Heritage Environmental Services. http://www.heritageenviron.com/what-are-k-listed-wastes/. Accessed 14 June 2020

Hester, RE; Harrison, RM (2016). Pharmaceuticals in the environment. In Issues in Environmental Science and Technology (p. 294). Royal of Society Chemistry.

Hope, J; Rodewald, J (2017). Waste Management: Issues and Regulations Regarding Pharmaceutical Waste Management. Hazardous Waste Experts. https://doi.org/https://www.hazardouswasteexper ts.com/wpcontent/uploads/2017/06/PharmaceuticalWasteM anagement.pdf

Isidori, M; Lavorgna, M; Russo, C; Kundi, M; Žegura, B; Novak, M; et al. (2016). Chemical and toxicological characterisation of anticancer drugs in hospital and municipal wastewaters from Slovenia and Spain. Environ. Poll. 219: 275-287.

Jahangirnejad, R; Goudarzi, M; Kalantari, H; Najafzadeh, H; Rezaei, M (2020). Subcellular organelle toxicity caused by arsenic nanoparticles in isolated rat hepatocytes. International $J$.
Occup. and Environ. Med. 11(1): 41-52.

Jaseem, M; Kumar, P; John, RM (2018). An overview of waste management in Indian perspective. Global J. Ener. and Environ. 6(3): 158-161.

Joe English; Drakopoulos, E (2020). UNICEF provides vital supplies for Nigeria's COVID-19 response.

UNICEF. https://www.unicef.org/press-releases/unicefprovides-vital-supplies-nigerias-covid-19response

Kar, S; Sanderson, H; Roy, K; Benfenati, E; Leszczynski, J (2020). Ecotoxicological assessment of pharmaceuticals and personal care products using predictive toxicology approaches. Green Chemistry (Vol. 22). https://doi.org/10.1039/c9gc03265g

Kilinc, FS (2015). A Review of Isolation Gowns in Healthcare: Fabric and Gown Properties. J. Eng. Fibers and Fabrics. 10(3): 155892

Kim, DH (2014). Nitrocellulose. Encyclopedia of Toxicology: Third Edition, 3: 540-542.

Mahadik, KR (2016). Comprehensive legislation on disposal of Pharmaceutical wastes in India - A critical study. Bharati Vidyapeeth Deemed University. $\quad$ Retrieved from http://hdl.handle.net/10603/125223

Matt, GE; Quintana, PJE; Zakarian, JM; Hoh, E; Hovell, MF; Mahabee-Gittens, M; et al. (2017). When smokers quit: Exposure to nicotine and carcinogens persists from thirdhand smoke pollution. Tobacco Control. 26(5): 548-556.

Mattos Simoes Mendonca, M; LaSenna, C; Tosti, A (2015). Severe Onychodystrophy due to Allergic Contact Dermatitis from Acrylic Nails. Skin Appendage Disorders. 1(2): 91-94.

McKnight, RH; Spiller, HA (2005). Green tobacco sickness in children and adolescents. Pub. Health Reports. 120(6): 602-606.

Moreira, J; Gonçalves, R; Coelho, P; Maio, T (2017). Eyelid dermatitis caused by allergic contact to acrylates in artificial nails. Dermatology Reports. 9(1): 36-37. https://doi.org/10.4081/dr.2017.7198

MPCA (2011). U-list of hazardous wastes. Minnesota Pollution Control Agency. 
Impact of Pharmaceutical Waste Generation and Handling.....

http://www.pca.state.mn.us/waste/pubs/business. $\mathrm{html} /$. Accessed 12 June 2020

NCBI (2020). Melphalan. National Centre for Biotechnology Information (NCBI). https://pubchem.ncbi.nlm.nih.gov/compound/mel phalan. Accessed 28 June 2020

Ngwuluka, N; Ochekpe, N; Odumosu, P; John, SA (2009). Waste management in healthcare establishments within Jos Metropolis, Nigeria. Waste management in healthcare establishments within Jos Metropolis, Nigeria. 3(12): 459-465

NIOSH (2004). Preventing Occupational Exposure to Antineoplastic and Other Hazardous Drugs in Health Care Settings. The National Institute for Occupational Safety and Health. https://www.cdc.gov/niosh/docs/2004-165/. Accessed 17 May 2020

OECD (2019). Pharmaceutical Residues in Freshwater - Hazards and Policy Responses. OECD Studies on Water. https://doi.org/10.1787/c936f42d-en

Oladimeji-Salami, JA; Lawal, FT; Ajasa, O; Afolayan, GO; Akindele, AJ; Olayemi, SO; Adeyemi, OO (2017). Evaluation of knowledge and practice of pharmaceutical waste disposal in hospitals and pharmacies within Lagos State, Nigeria. Nig. Quart. J. Hosp. Med. 27(2): 749-757.

Park, SJ; Lim, HS; Lee, K; Yoo, SJ (2018). Green Tobacco Sickness Among Tobacco Harvesters in a Korean Village. Safety and Health at Work, 9(1): 71-74.

1

Patel, M; Kumar, R; Kishor, K; Mlsna, T; Pittman, CU; Mohan, D (2019). Pharmaceuticals of emerging concern in aquatic systems: Chemistry, occurrence, effects, and removal methods. Chem. Rev. 119(6): 3510-3673.

Patil, GV; Pokhrel, K (2005). Biomedical solid waste management in an Indian hospital: A case study. Waste Manag. 25(6 SPEC. ISS.): 592-599.

Patlolla, AK; Tchounwou, PB (2005). Cytogenetic evaluation of arsenic trioxide toxicity in SpragueDawley rats. Mutation Research - Genetic Toxicol. and Environ.Mutagenesis, 587(1-2): 126-133.

Pines, E; Smith, C (2008). Managing Pharmaceutical Waste: A 10-Step Blueprint for Health Care Facilities In the United States. Health Care, 108.
Piotrowska, A; Czerwińska-Ledwig, O; Serdiuk, M; Serdiuk, K; Pilch, W (2020). Composition of scrub-type cosmetics from the perspective of product ecology and microplastic content. Toxicology and Environmental Health Sciences, 12(1): 75-81.

Qamar, W; Abdelgalil, AA; Aljarboa, S; Alhuzani, M; Altamimi, MA (2020). Cigarette waste: Assessment of hazard to the environment and health in Riyadh city. Saudi J. Biol. Sci. 27(5): 1380-1383.

Quinn, MJ (2015). Wildlife toxicity assessment for nitrocellulose. In Wildlife Toxicity Assessments for Chemicals of Military Concern (pp. 217 226). Amsterdam, the Netherland: Academic Press.

Ratnaike, RN (2003). Acute and chronic arsenic toxicity. Postgraduate Med. J. 79(933): 391-396.

Roig, Benoit; D’Acco, V (2016). Distribution of environmental residues in the environment. In R. E. Hester \& R. M. Harrison (Eds.), Pharm. in the environ. (pp. 34-69). Royal of Society Chemistry. https://doi.org/10.1039/9781782622345-00034

Russo, C; Lavorgna, M; Česen, M., Kosjek, T; Heath, $\mathrm{E}$; Isidori, M (2018). Evaluation of acute and chronic ecotoxicity of cyclophosphamide, ifosfamide, their metabolites/transformation products and UV treated samples. Environ. Poll. 233: 356-363. https://doi.org/10.1016/j.envpol.2017.10.066

Shannon, AL; Woolridge, A (2011). Med. Waste. Waste. Elsevier Inc. https://doi.org/10.1016/B978-0-12-3814753.10023-3

Soteriades, ES; Economidou, SC; Tsivitanidou, A; Polyviou, P; Lorimer, A; Katodritis, N; Theophanous-Kitiri, S (2020). Environmental assessment of cytotoxic drugs in the Oncology Center of Cyprus. PLoS ONE. 15(3): 1-11.

TAINÁ, GDF (2018). Environmental Risk Assessment and Toxicity of Pharmaceuticals in Coastal Tropical and Environmental Risk Assessment and Toxicity of Pharmaceuticals in Coastal Tropical and. University of Algarve. Retrieved from https://sapientia.ualg.pt/bitstream/10400.1/12726 /1/Thesis_final_Taina_Fonseca.pdf 
U.S. Environmental Proctection Agency (2005). Hazardous Waste Identification (40 CFR Parts 261). Solid Waste and Emergency Response, EPA530-K-O(September).

https:/www.epa.gov/sites/production/files/201509/documents/hwid05.pdf

Usawanuwat, J; Boontanon, N; Boontanon, SK (2014). Analysis of Three Anticancer Drugs Hydroxyurea ) in Water Samples by HPLC-MS / MS. Inter. J. Adv in Agric. \& Environ. Eng. 1(1): 72-76.

IUSEPA (2017). Defining Hazardous Waste: Listed, Characteristic and Mixed Radiological Wastes. United States Environmental Protection Agency. https://www.epa.gov/hw/defining-hazardouswaste-listed-characteristic-and-mixedradiological-wastes. Accessed 17 May 2020

Vallini, G; Townend, WK (2010). Pharmaceutical waste: As in the Titanic we are only seeing the tip of the iceberg. Waste Manage. and Res. 28(9): 767-768.

Verma, R (2020). Pharmaceutical Waste/Scrap Management. Pharmatutor. https://www.pharmatutor.org/articles/pharmaceut ical-wate-management. Accessed 22 July 2020

Voudrias, E; Goudakou, L; Kermenidou, M; Softa, A (2012). Composition and production rate of pharmaceutical and chemical waste from Xanthi General Hospital in Greece. Waste Manag. 32(7): 1442-1452.
WHO (1999). Guidelines for Safe disposal of unwanted pharmaceuticals in and after emergencies. World Health Organization, 1-31. https://doi.org/10.1590/s102049892000000300015

WHO (2014). Safe management of wastes from health-care activities. http://www.mercuryconvention.org/Portals/11/do cuments/BAT-BEP draft guidance/Waste_Incineration.pdf

WHO (2016). Dioxins and their effects on human health. World Health Organization. https://www.who.int/news-room/factsheets/detail/dioxins-and-their-effects-onhuman-health/. Accessed 15 June 2020

WHO (2017). Tobacco and its environmental impact: an overview. https://doi.org/ISBN 978-92-4151249-7

WHO (2018). Health-care waste. World Health Organization. https://www.who.int/newsroom/fact-sheets/detail/health-care-waste.

Accessed 12 June 2020

Zafar, S (2019). Medical Waste Management in Developing Countries. BioEnergy Consult. https://www.bioenergyconsult.com/medicalwaste-management/. Accessed 12 June 2020 